\title{
SISTEM ABSENSI BERBASIS FINGERPRINT DAN PELAPORAN REALTIME MELALUI SMS GATEWAY
}

\author{
Tholib Hariono ${ }^{1}$, Mucharommah Sartika Ami \\ ${ }^{1)}$ Fakultas Teknologi Informasi, Universitas KH. A. Wahab Hasbullah Tambakberas Jombang \\ ${ }^{2)}$ Fakultas Ilmu Pendidikan, Universitas KH. A. Wahab Hasbullah Tambakberas Jombang \\ Correspondence Author: harionotholib@unwaha.ac.id
}

\begin{abstract}
In an effort to improve student discipline of school rules, the prevailing student attendance becomes important in order to become a realiable student discipline student's benchmark. But in every school there is often a lot of fraud committed by students such as not going to school without explanation, home school is not appropriate, create a fake license. According to the attendance data that has been in $M A B U$ Tambakberas Jombang in the last 5 years has increased the number of student negligence every year. Lack of supervision of parents to students who are mostly students are student at traditional Muslim school Bahru Ulum Tambakberas Jombang who are parents can not supervise students as much as possible to trigger acts of fraud committed by students. The purpose of making this system is to reduce the level of student neglect and improve student discipline. Supported by fingerprint technology and sms gateway as daily report in and out of student, expected to reduce fraud done by student to control of parent will be discipline through attendance will remain assured and reduce the number of false permit.
\end{abstract}

Keywords: Attendance, SMS Gateway, Fingerprint, Realtime

\section{INTISARI}

Dalam usaha meningkatkan kedisiplinan siswa atas peraturan sekolah, absensi siswa yang valid menjadi hal penting agar bisa berfungsi menjadi tolok ukur laporan kedisiplinan siswa yang realiable. Namun di setiap sekolah sering terjadi kecurangan-kecurangan yang dilakukan oleh siswa seperti tidak masuk sekolah tanpa keterangan, pulang sekolah tidak pada semestinya, membuat surat ijin palsu. Menurut data absensi yang telah ada di MABU Tambakberas Jombang selama dalam kurun waktu 5 tahun terakhir ini mengalami peningkatan jumlah kealpaan siswa setiap tahunnya. Kurangnya pengawasan orang tua terhadap siswa yang dikarenakan sebagian besar siswa merupakan santri pondok pesantren Bahru Ulum Tambak Beras Jombang yang mengakibatkan orang tua tidak bisa mengawasi siswa semaksimal mungkin sehingga menjadi pemicu tindak kecurangan yang dilakukan oleh siswa. Tujuan pembuatan sistem ini yaitu menurunkan tingkat kealpaan siswa dan meningkatkan kedisiplinan siswa. Dengan didukung teknologi fingerprint dan sms gateway sebagai laporan harian keluar masuk siswa, diharapkan dapat mengurangi kecurangan yang dilakukan oleh siswa hingga pengontrolan orang tua akan kedisiplinan melalui absensi akan tetap terjamin dan mengurangi banyaknya surat ijin palsu.

Kata Kunci : Absensi, SMS Gateway, Fingerprint, Realtime 


\section{PENDAHULUAN \\ 1.1 Latar Belakang}

Fungsi penting dari adanya absensi siswa adalah memberikan informasi kehadiran siswa dari pihak sekolah kepada orang tua sebagai salah satu bentuk pelaporan progress belajar siswa. Sistem pendidikan dapat berjalan dengan baik bila siswa dapat hadir dalam proses belajar mengajar sehingga diperlukan pengawasan kedisiplinan yang dilakukan oleh sekolah. Umumnya kegiatan absensi saat ini masih menggunakan kertas, lalu guru memanggil satu persatu siswa dalam setiap matapelajaran, namun sistem absensi seperti ini tidak jarang memiliki banyak kekurangan misalnya ketidakvalidan data absensi atau hilangnya data maupun lamanya dalam merekap data informasi absensi siswa pada saat dibutuhkan.

Fungsi lain dari adanya absensi adalah sebagai bentuk pengawasan yang dilakukan oleh pihak sekolah kepada siswa, namun hal ini tidak serta-merta menjadi tanggung jawab pihak sekolah saja, peran serta secara aktif orang tua pun perlu dilakukan. Dalam prakteknya, peran pengawasan terhadap kehadiran siswa hanya dibebankan kepada pihak sekolah, namun banyak juga terjadi kesalahan pengawasan yang dilakukan baik sekolah maupun orang tua yakni belum adanya mekanisme komunikasi antara pihak sekolah dan orang tua dalam mengkontrol kehadiran siswa. Selain masalah tersebut, kelengahan yang diakibatkan kurang efektifnya pengawasan orang tua sering terjadi, seperti seorang anak berangkat dari rumah ke sekolah, namun anak tersebut tidak pernah sampai ke sekolah (bolos sekolah).

Fenomena terjadi pada siswa yang bertempat dipondok pesantren modern yang lokasi sekolahnya jauh dari pondok pesantren dimana siswa tersebut tinggal, sehingga pada prakteknya peran pengawasan orang tua semakin kurang dalam aspek disiplin siswa. Masalah- masalah pokok dalam pengawasan kehadiran siswa adalah kurang terjalinnya komunikasi antara pihak sekolah dengan para orang tua/wali, untuk itu diperlukan sistem komunikasi melalui media telepon selular guna menginformasikan ketidakhadiran siswa kepada orang tua.

\subsection{Rumusan Masalah}

Berdasarkan hasil pengamatan dan wawancara di MABU Tambakberas Jombang, maka ditemukan berbagai permasalahan pada sistem yang telah berjalan.

a. Belum adanya mekanisme penyampaian informasi kehadiran siswa dari pihak sekolah ke orang tua/wali murid.

b. Pengawasan orang tua tentang kehadiran siswa yang tidak maksimal karena 2 alasan, Pertama, Karena sebagian besar siswa merupakan santri pondok pesantren Bahrul Ulum. Kedua, Karena sistem pengawasan sekolah belum ada.

c. Tidak adanya pelaporan terhadap ketidakhadiran siswa kepada orang tua/wali murid sehingga orang tua/wali tidak memperoleh informasi terkait progress belajar siswa secara efektif.

\subsection{Batasan Masalah}

Batasan Masalah dari penulisan ini.

a. Membangun struktur basis data untuk membangun pengolahan data dalam penyampaian informasi kehadiran siswa di sekolah kepada orang tua.

b. Media yang digunakan untuk mendukung sistem terdiri dari modem, kartu telelpon selular, telepon selular dan sidik jari.

\subsection{Tujuan \& Manfaat Penulisan}

\subsubsection{Tujuan Penelitian}

Adapun tujuan dari penelitian yang ingin dicapai adalah sebagai berikut :

a. Membangun sistem penyampaian ketidakhadiran siswa yang dapat meningkatkan kontrol terhadap kedisiplinan siswa.

b. Sistem ini diharapkan dapat memberikan alternative pilihan dalam guna menunjang sistem pembelajaran di sekolah 


\section{TINJAUAN PUSTAKA DAN LANDASAN TEORI}

\subsection{Tinjauan Pustaka pada Penelitian ini Direferensi dari beberapa penelitian sebelumnya yaitu :}

a. Naslim Lathif, Achmad Hidayatno, R. Rizal Isnanto. 2001. Aplikasi Sidik Jari Untuk Sistem Presensi Menggunakan Magic Secure.

b. Dwi Agus Dartono, 2010. Integrasi Sistem Finger Print dan Sistem Sms Gateway untuk Monitoring kehadiran Siswa.

c. Khoirur Rozikin, Kasih Purwantini, 2014. Pengaruh Sistem Presensi dengan Deteksi Sidik jari dan SMS Gateway Terhadap Tingkat Membolos Siswa.

\subsection{Landasan Teori}

\subsubsection{Short Message Service (SMS)}

Pesan pendek short messaging system (SMS) merupakan salah satu model komunikasi yang masih bisa diandalkan saat ini. Implikasinya, SMS adalah salah satu model komunikasi yang bisa digunakan melakukan transaksi dengan database. SMS Gateway merupakan sistem layanan yang dibuat khusus untuk menciptakan sistem layanan baik satu arah maupun dua arah. Pada prinsipnya, SMS Gateway adalah sebuah perangkat lunak yang menggunakan bantuan komputer dan memanfaatkan teknologi seluler yang diintegrasikan guna mendistribusikan pesan-pesan yang digenerate lewat sistem informasi melalui media SMS yang di-handle oleh jaringan seluler. (Miron Romzi, 2006).

\subsubsection{Sidik Jari}

Sidik jari (fingerprint) atau bisa disebut Dactyloscopy merupakan ilmu yang mempelajari sidik jari yang dipergunakan untuk keperluan pengenalan kembali identitas seseorang dengan cara mengamati garis yang terdapat pada guratan garis jari tangan dan telapak kaki. Fingerprint ini memiliki Fungsi untuk memberi gaya gesek lebih besar agar jari dapat memegang benda-benda lebih erat. Sidik jari manusia digunakan untuk keperluan identifikasi karena tidak ada dua manusia yang memiliki sidik jari persis sama. Hal ini mulai dilakukan pada akhir abad ke-19.

Penekanan pada sidik jari memiliki makna sangat khusus. Ini dikarenakan sidik jari setiap orang adalah khas bagi dirinya sendiri. Setiap orang yang hidup atau pernah hidup di dunia ini memiliki serangkaian sidik jari yang unik dan berbeda dari orang lain. Itulah mengapa sidik jari dipakai sebagai kartu identitas yang sangat penting bagi pemiliknya dan digunakan untuk tujuan ini di seluruh penjuru dunia. Akan tetapi, yang penting adalah bahwa keunikan sidik jari ini baru ditemukan di akhir abad ke-19. Sebelumnya, orang menghargai sidik jari sebagai lengkunganlengkungan biasa tanpa makna khusus. Setiap orang, termasuk mereka yang terlahir kembar identik, memiliki pola sidik jari yang khas untuk diri mereka masingmasing, dan berbeda satu sama lain. Dengan kata lain, tanda pengenal manusia tertera pada ujung jari mereka. Sistem pengkodean ini dapat disamakan dengan sistem kode garis (barcode) sebagaimana yang digunakan saat ini. (Miron Romzi, 2006).

\section{METODOLOGI PENELITIAN}

Metode yang diterapkan untuk perancangan sistem absensi, yaitu :

\subsection{Waterfall}

Tahapan Waterfall Model adalah sebagai berikut:Pertama, Requirements analysis and definition Requirements analysis and definition dilakukan terhadap data yang ada serta mengumpulkan kebutuhan kebutuhan perangkat lunak yang akan dibangun. Merupakan tahap dimana inisialisasi pendefinisian masalah untuk penyelesaian teknis pengembangan perangkat lunak mulai dilakukan. Terminasi tahap analisis, pada saat telah didapatnya definisi permasalahan yang disetujui oleh pengguna dan pengembang. Kedua, System and software design. Pada tahap

ISSN Print : : 1979-7141 
desain dilakukan pengubahan kebutuhan-kebutuhan menjadi bentuk karakteristik yang dimengerti perangkat lunak sebulum dimulai penulisan program. Adapun proses yang dilakukanpada tahap ini adalah:

a. Mendekomposisi modul sistem yang akan dikembangkan

b. Penetapan rancangan masukan dan keluaran yang diperlukan

c. Penetapan struktur data yang dipilih

d. Penetapan prosedur kerja internal

e. Penetapan formula pengolahan data

Ketiga, Implementasi and unit testing. Pada tahap ini, perancangan perangkat lunak direalisasikan sebagai serangkaian program atau unit program. Pengujian unit melibatkan verifikasi bahwa setiap unit telah memenuhi spesifikasinya. Keempat, Integration and system testing. Unit program atau program individual diintegrasikan dan uji sebagai sistem yang lengkap untuk menjamin bahwa persyaratan sistem telah dipenuhi. Kelima, Operation and maintenance normally. Ini merupakan fase siklus yang paling lama. Pemeliharaan mencakup koreksi dari berbagai error yang tidak ditemukan tahap-tahap sebelumnya. disamakan dengan sistem kode garis (barcode) sebagaimana yang digunakan saat ini.

\subsection{Analisis Sistem (System Analysis)}

Tahap selanjutnya setelah dilakukan perencanaan adalah melakukan analisis terhadap sistem yang berjalan saat ini untuk diidentifikasi kekurangan-kekurangan dari sistem yang berjalan, sehingga pada tahapan ini dilakukan analisis terhadap sistem yang berjalan.

Sistem absensi siswa yang berjalan adalah sebagai berikut:

1. Setiap guru mata pelajaran mengajar akan memanggil satu persatu siswa atau guru akan menyerahkan form absensi kepada siswa yang ditunjuk.

2. Siswa akan menandai form absensi kehadiran teman-temannya dan menyerahkan kembali kepaga guru mata pelajaran.

3. Setiap akan melaksanakan ujian tengah semester dan ulangan umum, guru kelas akan membuat laporan kehadiran masing-masing siswa kelas per mata pelajaran dan diserahkan kepada wali kelas..

4. Wali kelas akan melakukan evaluasi dan pembinaan terhadap siswa yang kehadirannya dibawah $70 \%$ untuk meningkatkan hasil belajar siswa.

Sistem penyampaian ketidakhadiran siswa yang berjalan adalah sebagai berikut :

1. Setiap periode, wali kelas merekap data kehadiran siswa dan memilih data kehadiran siswa yang kurang dari $70 \%$.

2. Berdasarkan data tersebut, wali kelas membuat surat peringatan untuk masingmasing siswa yang bermasalah tersebut dan dilaporkan kepada kepala sekolah untuk ditandatangani dan diteruskan kepada wali murid masing-masing untuk dilakukan tindakan pembinaan kedisiplinan siswa.

\section{HASIL DAN PEMBAHASAN}

\subsection{Perancangan Sistem}

1. Perancangan Alur 1.

Sistem yang diusulkan dijelaskan menggunakan diagram use case yang bisa dilihat pada gambar 


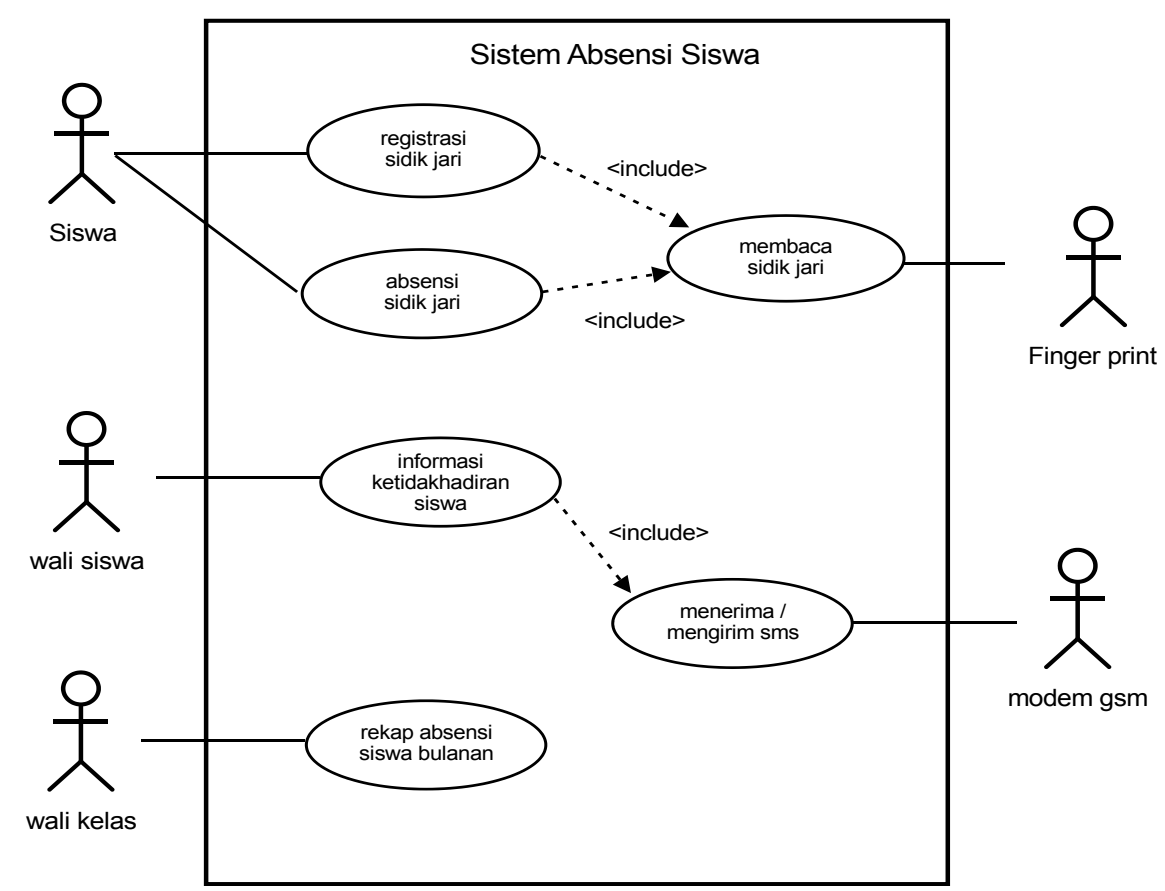

Gambar 1 Diagram Use Case Sistem Absensi

2. Perancangan Basis Data

Perancangan Basis Data digambarkan dalam bentuk Entity Relationship Diagram (ERD) yang dapat dilihat pada gambar 2 .

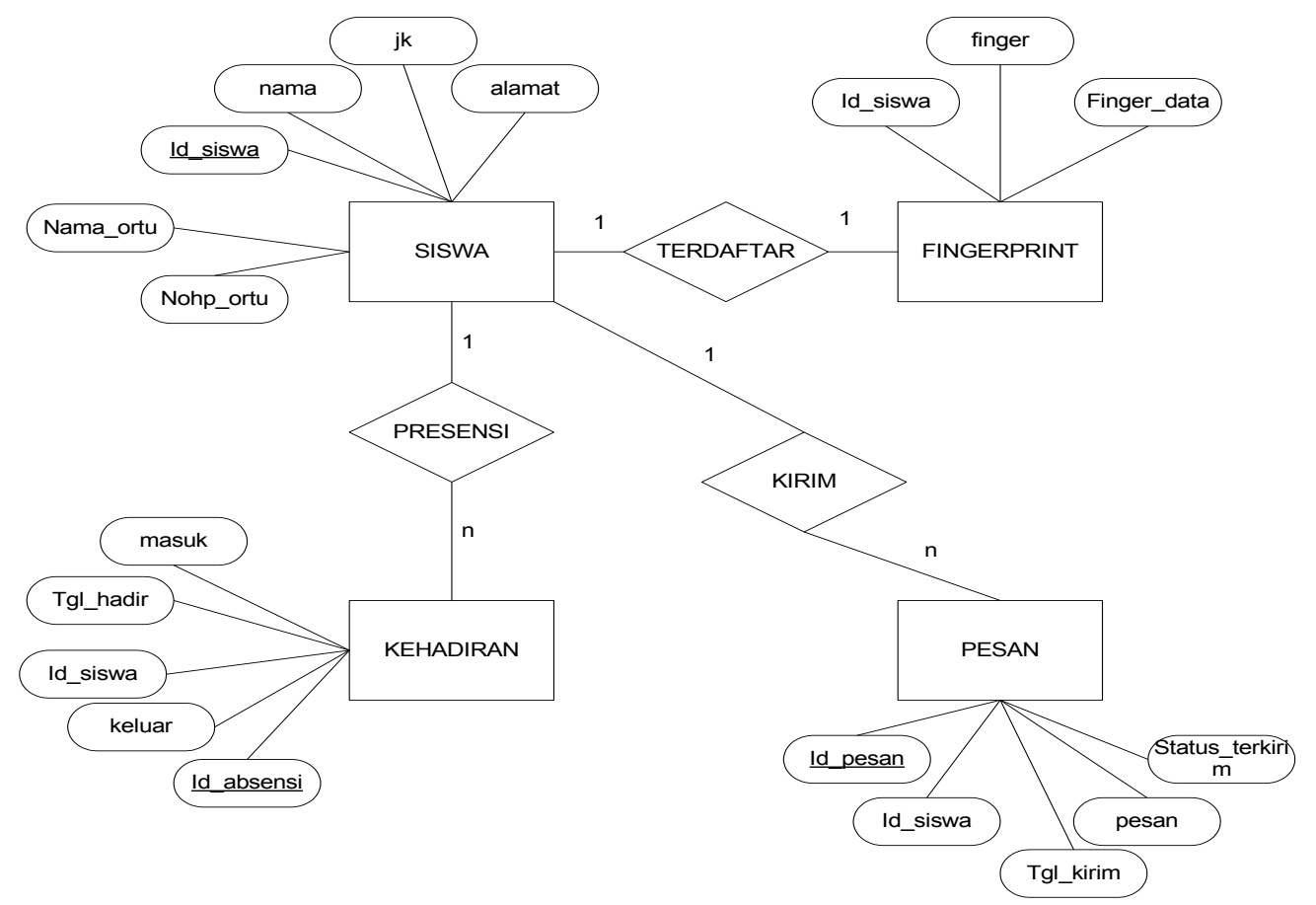

Gambar 2. ERD Sistem Absensi 


\subsection{Tampilan Aplikasi}

1. Form Utama

Form utama merupakan tampilan utama dari aplikasi sistem absensi ini. Pada form utama terdapat 7 pilihan menu untuk membuka form yang lain. Tampilan form utama dapat dilihat pada gambar 3 .

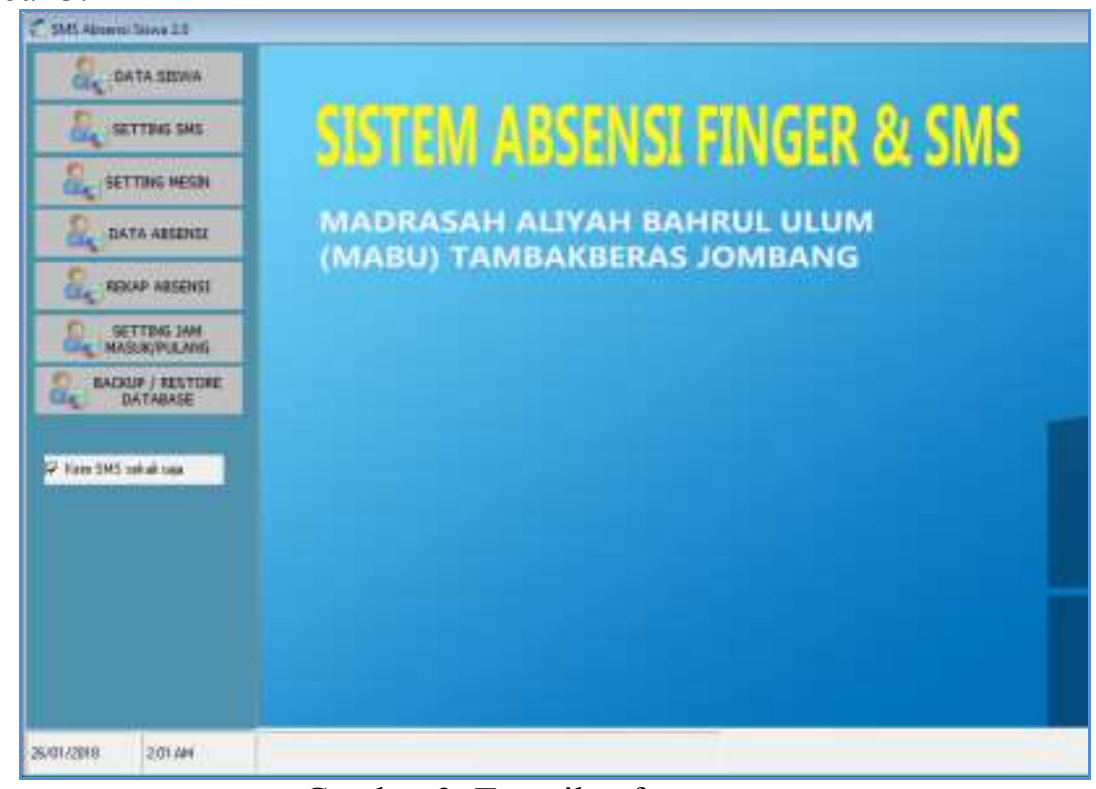

Gambar 3. Tampilan form utama

2. Form Data Siswa

Form ini digunakan untuk menginputkan data siswa. Selain itu terdapat filter untuk menampilkan siswa berdasarkan kelas, pencarian data siswa berdasarkan nama. Fasilitas lainnya terdapat import siswa untuk menginputkan siswa secara massal dalam format excel dan export siswa untuk mengambil data siswa untuk disimpan dalam format excel. Bentuk form data siswa dapat dilihat pada gambar 4.

\begin{tabular}{|c|c|c|c|c|c|c|c|c|c|c|}
\hline \multicolumn{11}{|c|}{ 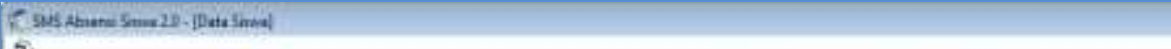 } \\
\hline \multicolumn{11}{|c|}{5} \\
\hline \multirow{2}{*}{$\frac{d_{s} \text { data sawa }}{d_{5} \text { setrag sak }}$} & \multicolumn{10}{|c|}{ MASTER DATA SISWA } \\
\hline & \multicolumn{2}{|c|}{ 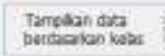 } & $\sqrt{\mathrm{AI}}$ & \multicolumn{3}{|c|}{ Nersiliare } & & & \multirow[t]{2}{*}{ chets } \\
\hline \multirow{3}{*}{ Cog grtrac vesm } & $H_{D}$ & nof Pnjer & QTS & Mems & Ip & ones & MF OTy & Alarut & Pot & \\
\hline & 1 & 2342 & 2942 & M. Frid. & i & $120 \mathrm{PAL}$ & 085722312334 & & E] & \\
\hline & & 272 & 2012 & What sa Henventi & if & $120 \times 1$ & omprozza:47 & & DI & \\
\hline \multirow{2}{*}{ Cs data rasegil } & 3 & 2800 & 2000 & Matron & i & II2pa! & 68528748345 & & D & \\
\hline & 4 & स्था & 제 & sekotan & If & $128 \% 1$ & acm2259173 & & D. & \\
\hline \multirow{3}{*}{ 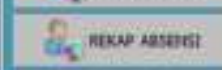 } & & 2815 & 2915 & 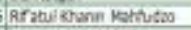 & is & $12 \mathrm{PAt}$ & 063953329600 & & DI & \\
\hline & to & 200 & 7009 & 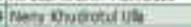 & 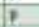 & 120161 & & & (2) & \\
\hline & 7 & 2600 & 2300 & Heen Prove & ip & 12PM! & 065791790007 & & 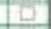 & \\
\hline \multirow{3}{*}{ Os misin mu } & B & 2ज्ञात & 290 & Merris Solent & F & 32PAT & gextset5:27 & & int & \\
\hline & 9 & 2801 & 2901 & Wilt Dro Kenut & 7 & $12 \times 1$ & BESAS245:27 & & 마 & \\
\hline & 10 & 200 & $n=0$ & Le derian. & 7 & 17304 & Cetsentsopas & & 0.1 & \\
\hline \multirow{4}{*}{ 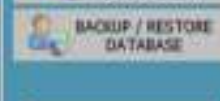 } & 21 & 2797 & 279 & Lataulkafush & is & $12 \mathrm{PMI}$ & $08155288265]$ & & D. & \\
\hline & 12 & 2200 & 2000 & Lexilhicroent & ib & T2DAt & 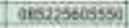 & & an & \\
\hline & 13 & 2792 & 2790 & Ersa Har laeb & 7 & 12012 & 085706172381 & & D] & \\
\hline & 14 & 2706 & 7701 & Eonomimasis & is & 22842 & 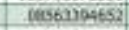 & & (4) & \\
\hline \multirow{11}{*}{ 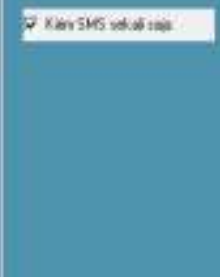 } & is & 2709 & 200 & Owi lis farca & p & $12 \mathrm{PAl}$ & $065335 \% 44753$ & & D & \\
\hline & in & 27 畺 & 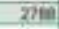 & Don Ca fotrian & i & 120041 & 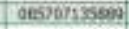 & & 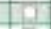 & \\
\hline & it & 2785 & 2765 & Na Whenet & $i$ & 12PA1 & 062333560420 & & D & \\
\hline & in & 2769 & 2764 & 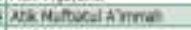 & i & 12004t & GES5sis6125e & & 맘 & \\
\hline & is & 310 & 3230 & Ridontan & $\frac{1}{t}$ & I2FAt & & & 뭄 & \\
\hline & 20 & काI & 3911 & Fachan NI & i & 23204 & & & क्ष & \\
\hline & z & 3012 & 3912 & B.od Mazara & I & 2ZPA! & & & 마 & \\
\hline & 22 & 2702 & 270 & 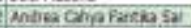 & $i$ & 12001 & $062125: 65529$ & & 마 & \\
\hline & 23 & 2781 & 2781 & 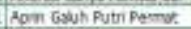 & $f$ & $12 \mathrm{PA1}$ & OB1J5A15T709 & & 만 & \\
\hline & 26 & 2817 & 2017 & paresilasath & $i$ & i2psis & 062132464543 & & 도 & \\
\hline & \multicolumn{2}{|c|}{ frosit Sons } & & Delecte & & \multicolumn{2}{|c|}{ Eoortsons } & & & \\
\hline 350120019 & & & & & & & & & & \\
\hline
\end{tabular}

Gambar 4. Tampilan form data siswa 
3. Form Kehadiran Siswa

Form ini berfungsi untuk menampilkan kehadiran siswa pada tanggal tertentu serta untuk mengetahui status SMS kehadiran yang dikirim ke orang tua siswa. Tampilan form ini dapat dilihat pada gambar 5 .

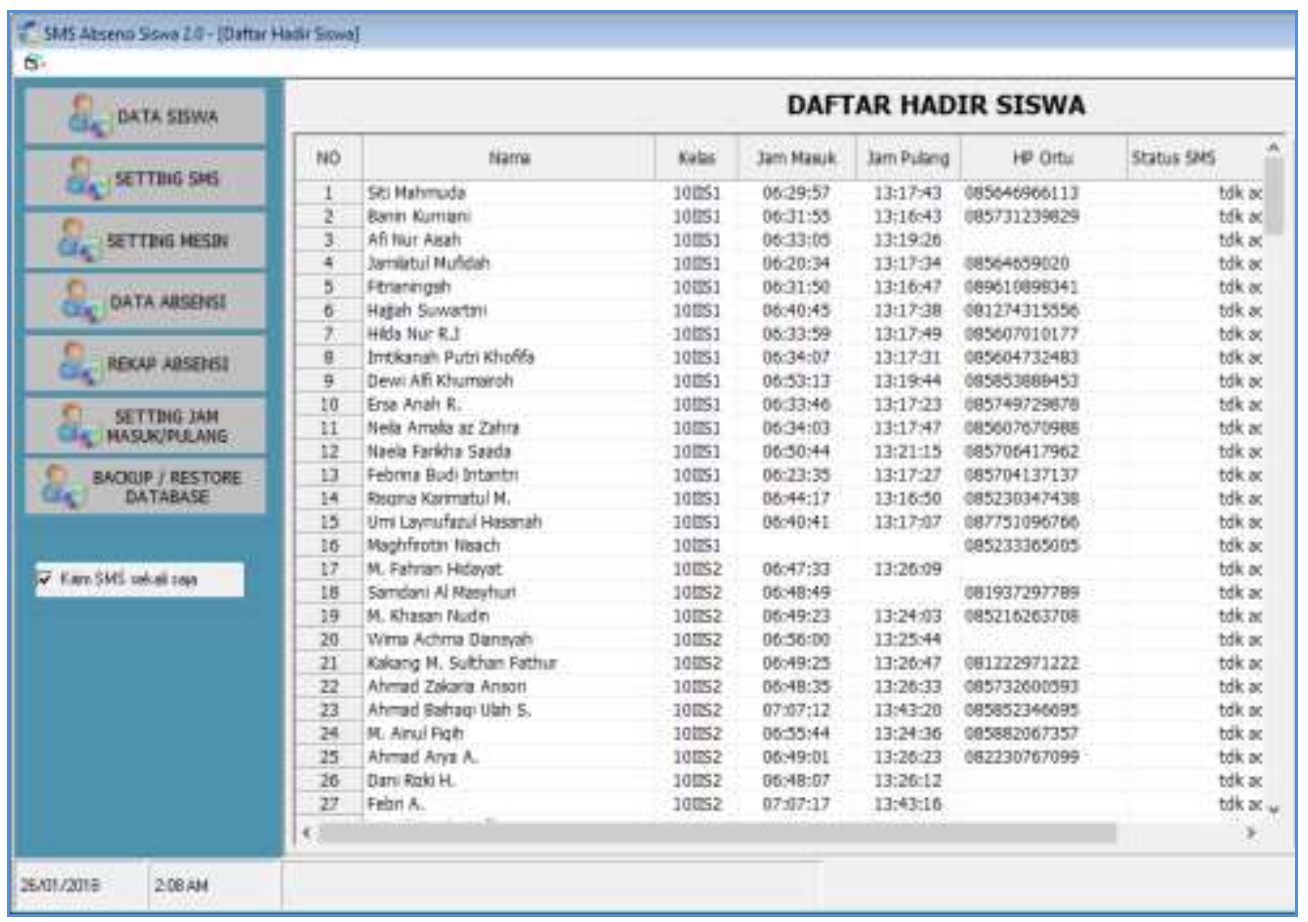

Gambar 5. Form kehadiran siswa

4. Form Rekap absensi

Form ini digunakan untuk merekap kehadiran siswa selama satu bulan, dengan menentukan pilihan bulan, tahun serta pilihan kelas. Terdapat tombol export data yang digunakan untuk menyimpan rekap absensi dalam format excel yang dapat digunakan untuk berbagai keperluan. Tampilan form ini dapat dilihat pada gambar 6 .

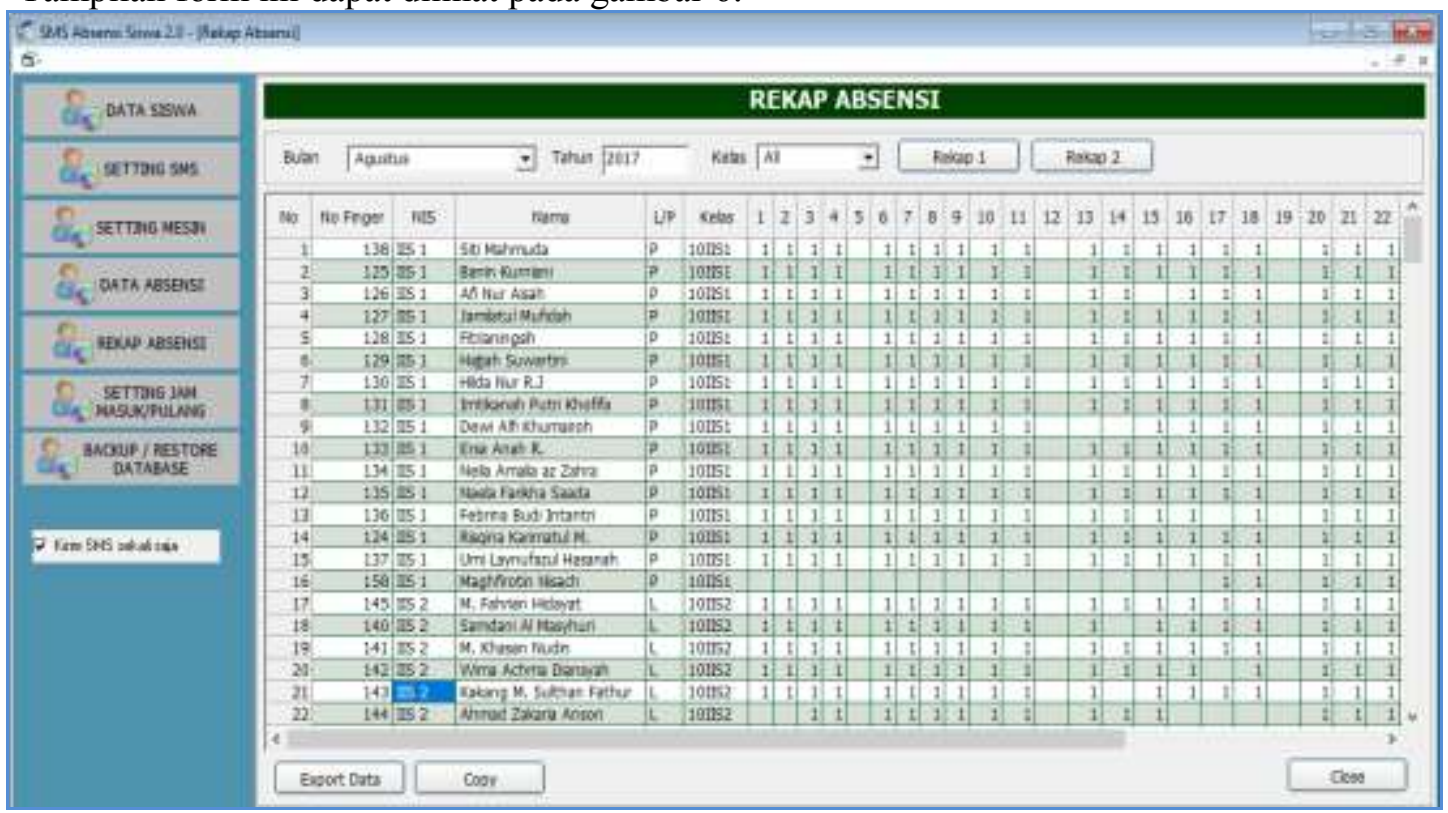

Gambar 6. Form rekap absensi 


\section{KESIMPULAN}

Program aplikasi yang digunakan dalam mengolah data absensi dan laporan ketidakhadiran siswa ini telah dapat digunakan untuk membantu MABU. Pemasalahan yang selama ini terjadi dapat teratasi dengan baik dan kendala-kendala yang terjadi dapat diminimalisir. Aplikasi dibuat menggunakan bahasa pemograman visual basic 6.0 dengan database SQL Server 2000 dan barbasis jaringan sehingga dapat diakses oleh bagian-bagian yang terkait. Kelebihan Sistem baru yang dibuat untuk Aplikasi Pengolahan Data abasensi dan penyampaian ketidakhadiran pada MABU yaitu:

a) Penyampaian informasi kehadiran siswa dilakukan secara realtime kepada orang tua setelah siswa melakukan presensi sidik jari.

b) Informasi yang disampaikan kepada orang tua berupa waktu kehadiran siswa di sekolah (pada saat presensi sidik jari) sehingga orang tua akan mengetahui putra-putrinya terlambat atau tidak.

c) Aplikasi ini akan memudahkan user pada saat penambahan data, penyimpanan data, pengubahan data maupun pencarian data

d) Data yang tersimpan sudah terkomputerisasi sehingga kecil kemungkinan untuk kehilangan data dibandingkan menggunakan metode pengarsipan.

e) Aplikasi telah berbasis jaringan yang dapat memudahkan antar bagian dalam mengolah data sesuai dengan otoritas dan database menjadi satu sehingga memudahkan dalam mengelolanya. 


\section{DAFTAR PUSTAKA}

Dwi Agus Dartono, 2010. Integrasi Sistem Presensi Finger Print dan Sistem Sms Gateway untuk Monitoring Kehadiran Siswa. Jurnal Teknologi Informasi Dinamik XV. No.1.

Khoirur Rozikin, Kasih Purwantini, 2014. Pengaruh Sistem Presensi dengan Deteksi Sidik jari dan SMS Gateway Terhadap Tingkat membolos Siswa, ISBN: 979-26-0276-3.

Mirón Romzi, 2006. Membuat Sendiri SMS Gateway (ESME) Berbasis Protokol SMPP, Penerbit Andi, Jogyakarta

Naslim Lathif, Achmad Hidayatno, R. Rizal Isnanto. 2001. Aplikasi Sidik Jari Untuk Sistem Presensi Menggunakan Magic Secure

Sommerville, Ian. 2007. Software Engineering 8thn, England: Addison Wesley. 